\title{
Determinants of Tax Revenue in Sierra Leone: Application of the ARDL Framework
}

\author{
Abu Bakarr TARAWALIE ${ }^{1} \&$ Sia HEMORE $^{1}$ \\ ${ }^{1}$ Department of Economics and Commerce, University of Sierra Leone, Sierra Leone \\ Correspondence: Abu Bakarr Tarawalie, Department of Economics and Commerce, University of Sierra Leone, \\ Sierra Leone. Email: tarawalieabu@yahoo.com
}

Received: November 15, 2021; Accepted: November 29, 2021; Published: December 2, 2021

\begin{abstract}
The aim of this paper is to investigate the determinants of tax revenue in Sierra Leone, over the period 1990Q1 to 2020Q1, within the context of the ARDL estimation procedure. The result from the ARDL Bound test for cointegration suggests that a long-run relationship exists among the variables. The long run analysis indicates that real GDP (Y), openness (Op) and official development assistance (ODA) are the main determinants of tax revenue (TR) in Sierra Leone, with positive coefficients. This result is in tandem with the short run findings, which establishes a positive relationship between tax revenue and its regressors- real GDP and openness. However, the short run result also suggests that inflation has a negative impact on tax revenue. The findings confirm that any short-run disequilibrium to the long-run can be corrected at the 11 percent speed of adjustment quarterly, albeit at a low speed of adjustment. The diagnostic result shows that approximately 75 percent of the variation in the dependent variable is explained by the regressors based on the value of the R-squared. It also confirms that the model is free of serial correlation and heteroscedasticity, whilst the CUSUM test indicates stability of the model coefficients.
\end{abstract}

The policy implication is for government to pursue policies that will enhance economic growth, through investment in growth enhancing sectors including agriculture, health, education, energy and infrastructure development; and ensure a politically stable environment as a recipe for private sector investment.

Keywords: Sierra Leone, tax revenue, quarterly data, ARDL

JEL Classification: $\mathrm{H} 2, \mathrm{H} 20$

\section{Introduction}

There is a growing recognition in the literature that reliance on external financing for development is not sustainable. Not only is this source of funding unpredictable, but it also limits a country's policy space, reduce its sense of ownership in the development process, and lead to debt sustainability problem in the long term (Gupta, 2007). Meanwhile, in recent times, the issue of Domestic Resource Mobilization (DRM) is occupying a place of special significance in development plans such as the Istanbul Programme of Action (IPoA), the Monterrey Consensus on Financing for Development in 2002, the Sustainable Development Goals (SDGs) 2030, and the African Union's Agenda 2063. Besides, suggestions abound that domestic resource mobilization can help developing countries enhance economic growth and development (Wujung and Aziseh 2016; Takumah and Iyke 2015). Apparently, taxation is considered irreplaceable in nation building (Ojong et al., 2016). While its role in the economy is fundamental, it is the most critical source for generating revenue domestically. In most situations, tax revenue is considered a major source of government revenue for both developed and developing countries (Abdixhiku et al., 2017). Generally, governments use the revenue from taxes to provide public goods, invest in physical and institutional infrastructure, and provide social welfare programmes. Furthermore, tax revenue helps government in planning process, implementation of development agenda, promote private sector development, settlement of government obligations, and serve as a strong conduit that will enhance effective distribution of resources. Furthermore, the rationale for effective domestic revenue mobilization is also premised on the need to minimize the high dependency on foreign aid, limit the quest for foreign borrowing, ensure prudent macroeconomic management, and hence boost economic growth.

Most developing countries are besieged by large fiscal imbalances (fiscal deficits) triggered by excessive government expenditure albeit low domestic revenue mobilization. In pursuit of mobilizing enough domestic revenue to fund developmental projects, most developing countries including Sierra Leone, are plagued with 
political issues, weak institutional capacities, low development, inefficient tax system, large underground economic activities, and chronic tax evasion and avoidance. If African countries are able to rely on domestic revenue and other internal source of funding, then it will decrease their reliance on external funding for developmental projects (Aggrey, 2013). It will also allow them to leverage on their domestic priorities with funding from domestic sources rather than relying on donor funding with its attendant conditionalities attached to such funding.

Thus far, African governments have shown strong commitments in enhancing robust revenue administrations through modernized, progressive tax systems, improved tax policy and efficient tax collection. Moreover, reforms have also been undertaken for the financial sector which is a vital component for the enhancement of domestic resource mobilization. While tax revenue (\% GDP) has improved over the years in Africa, the region lags in comparison to other regions. Available statistics suggests that, between 2000 to 2018, tax-to-GDP was $16.5 \%$ for Africa, $23.1 \%$ for Latin America and the Caribbean, and 34.3\% for OECD ( OECD/ATAF/AU, 2020). With this, improvement in the region's domestic resource mobilisation is imminent since an increased resource inflow poses some serious risk which can even lead to low savings rates. The literature suggests that fiscal imbalance continue to pose severe challenge for most developing countries, largely attributed to surge in government expenditure, while revenue mobilization remains low (Ansari, 1982). In an effort to bolster revenue mobilization, through effective tax reforms and efficient tax system, most developing countries are besieged by structural bottlenecks relating to weak institutions, low economic activities, high tax evasion and tax avoidance, large informal sector and high corruption.

Given the quest to improve domestic revenue mobilization, the government of Sierra Leone, created the National Revenue Authority (NRA), with the mandate to assess and collect revenue, and make consequential amendments to laws relating to revenue. Since its establishment, NRA has introduced and updated several initiatives and Acts, including the development of the Finance Act, Domestic Act and Customs Act. Domestic revenue mobilization is regarded as a major tool used by the government of Sierra Leone in achieving its poverty reduction strategy and agenda for prosperity, create financial independence and with a foresight in transitioning to middle income status. Although Sierra Leone's Tax revenue (\% GDP) has generally been improving, it is however, below the $20 \%$ minimum required by the United Nations (2015) to achieve the SDGs. Furthermore, between from 2000 to 2018 , the country's tax revenue (\% GDP) averaged around 9\%, which is almost twice less than the average of Africa $(16.5 \%)$.

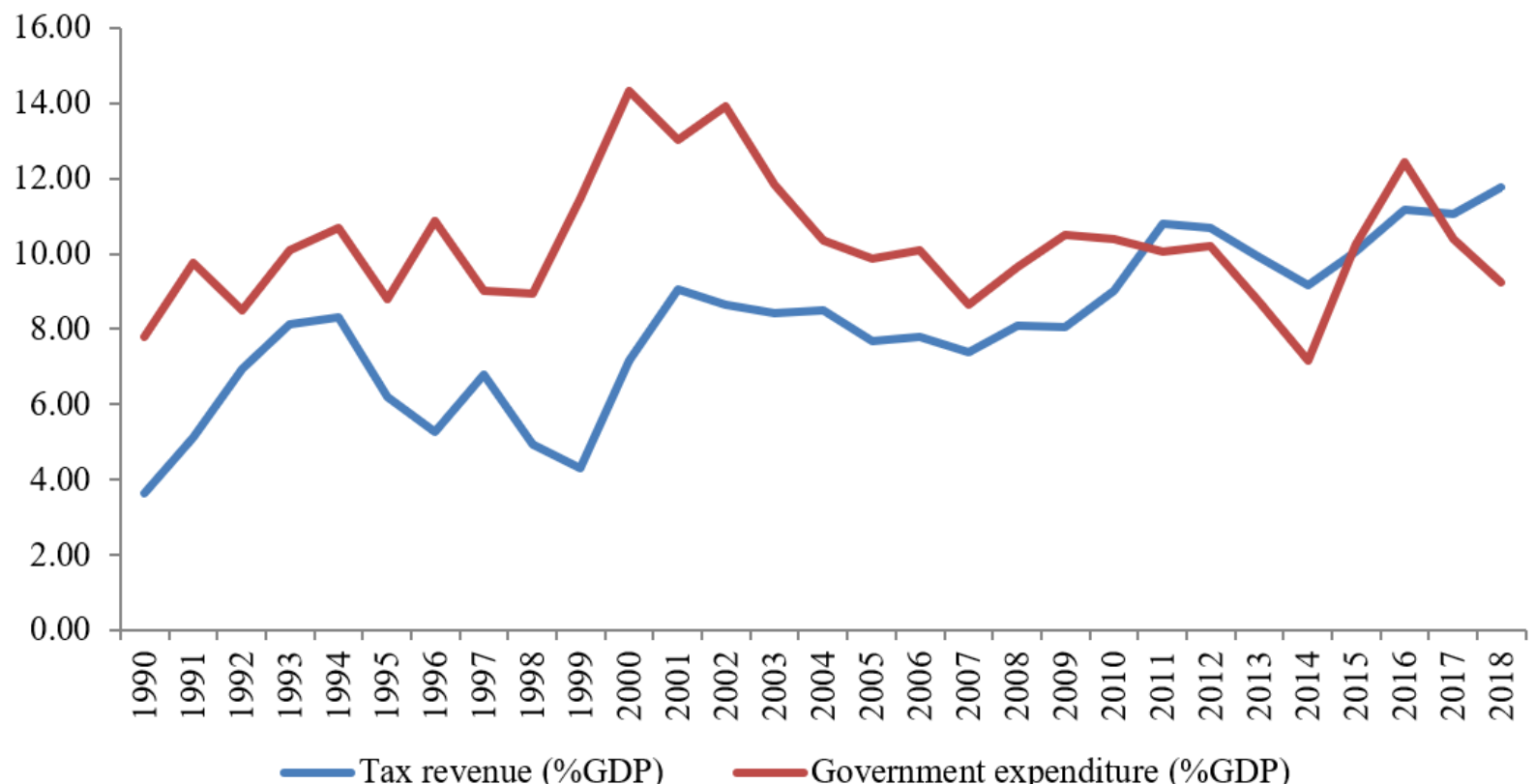

Figure 1. Trend in Tax Revenue and Government Expenditure as a percentage of GDP

Source: WDI (2021) and IMF (2021) 
Although tax revenue (\% GDP) for Sierra Leone has been lower than the Africa average, yet it has generally improved over the years- see Figure 1. Tax revenue (\% of GDP) increased from 3.6\% in 1990 to $8.3 \%$ in 1994. It however declined significantly on average between 1994 to 1999, largely on account of the political impasse that besieged the country during this period, which led to a slowdown in economic activities and a decline in revenue mobilization. Following the end of the civil conflict, there was renewed hope as economic activities picked up, and investment surged. Stability in the political arena also enhanced investments in the telecommunications sector and a revamp of the mining activities (UNCTAD Sierra Leone, 2010), which subsequently led to a sharp increase in tax revenues to $9.1 \%$ in 2001. However, between 2001 and 2008, tax revenue stagnated at an average of $8 \%$ of GDP, but increased gradually thereafter, and averaged 9.8\% between 2009-2012. However, tax revenue experienced a declining trend between 2013 and 2014, partly due to the closure of the two largest mines coupled with the impact of the Ebola disease. Following a rebound of the economic from the Ebola outbreak, tax revenue collection improved between 2015-2018, with tax revenue to GDP at 12\% in 2018. The increase in tax revenue was largely due to stability in the political landscape, coupled with increased economic activities especially in the mining and services sectors. In tandem with tax revenue (\% of GDP), government expenditure (\% of GDP) was juxtaposed with tax revenue. It is evident from Figure 1, that government expenditure outweighs the tax revenue. On average, between 1990 and 2018, government expenditure accounted for 10\% of GDP annually compared to 8\% of tax revenue. However, between 2012 and 2014, tax revenue (\% of GDP) exceed government expenditure (\% of GDP), largely on account of increased revenue mobilization from increased mining activities.

Over the years, the country implemented various measures aimed at obtaining optimal fiscal policies with emphasis on the role of taxation as an instrument of economic development. Notwithstanding such efforts, domestic revenue mobilization remains subdued and the country continue to rely on external source of funding and domestic borrowing to finance its investment requirement. Often, the country relies on official development assistance from abroad to finance its infrastructure project. However, this sort of financing is volatile and unpredictable. More so, excessive reliance on this type of source of financing could lead to a debt trap in the long-run (Neog and Gaur, 2020). As such, an effort to raise revenue domestically is imperative since it provides a more stable source of revenue generation which is crucial for medium- and long-term planning.

The objective of this study is to identify the main determinants of tax revenue in Sierra Leone. The study uses quarterly data for the period 1990Q1 to 2020Q1, and employs the autoregressive distributed lag (ARDL) estimation technique. The approach is a dynamic heterogeneous model that allows for both dependent and independent variables to be lagged and difference. The technique is preferred in situations where the variables are of I(0) and I(1) which gives a realistic and efficient estimates (Nkoro and Uko, 2016). The study is organized as follows: Section two articulates the empirical findings in the literature on the main drivers of tax revenue. Section three discusses the methodology, while section discusses the results. Section five conclude the study and proffer recommendations.

\section{Literature Review}

The empirical literature on the main determinants of tax revenue has produced mixed findings, largely due to differences in methodology, time period and characteristics of countries. Most of the research findings have established a relationship between tax revenue and a set of institutional, developmental and structural variables. In a recent study, AL-Qudah (2021) examined the fundament factors that determine tax revenue in Jordan from 1990-2019. Using an ARDL Bound testing model, the findings established a negative relationship between foreign aid tax revenue. However, the result showed that per capita GDP, fiscal deficit and government expenditure had a positive impact. Similarly, using the ARDL methodology, Amoh and Adom (2017) investigated the determinants of tax revenue in Ghana for the period 1975 to 2015. The findings showed that foreign direct investment, external debt, government expenditure, manufacturing and services sectors were the main determinants of tax revenue. Jaffri, et al., (2015) also used ARDL to investigate the relationship between trade liberalization and tax revenue in Pakistan from 1982 to 2013. The findings established a positive relationship between trade liberalization and tax revenue.

Boukbech et al. (2018) explored the main factors influencing tax revenues using a panel data for 29 lower middleincome countries from 2001 to 2014. The findings showed that per capita GDP and the value added of agriculture had a positive impact on tax revenues, whilst foreign debt exhibited negative effect. Castro and Camarillo (2014) investigated the determinants of tax revenue for 34 OECD countries, using panel data techniques from 2001 to 2011. The result found that GDP per capita, the industrial sector, and civil liberties had a positive effect on tax revenue; whilst a negative impact was obtained for agricultural sector and Foreign direct investment. Furthermore, Agbeyegbe et al (2006) conducting a study for 22 sub-Saharan Africa (SSA) countries from 1980 to 1996. Using the generalized method of moments estimation technique, the result indicated that exchange rate depreciation and 
inflation were the main drivers of tax revenue, and both variables had a negative impact. Similarly, Garg et al. (2014) examined the determinants of tax revenues for 29 Indian States from 1992 to 2011. They found that tax capacity is largely determined by the tax base, including economic, demographic, political variables. Addison and Levin (2012) undertook a study to determine the main drivers of tax revenue in 39 SSA countries using an unbalanced panel data from 1980 to 2005. Their findings showed that agricultural sector and foreign aid had negative effect on tax revenue. However, a positive impact was obtained for VAT and peaceful environment. Gurdal, et al., (2020) conducted a study to examine the causality between tax revenue and its determinants for the period 1980 to 2006 using seven great countries. The findings revealed a uni-directional causality from economic growth to tax revenue. Teref and Teera (2018) carried out a study on the determinants of tax revenue for East African countries using cross-sectional data from 1992 to 2015. They found that foreign aid, trade openness, GDP per capita, agriculture, services and industry had positive effect on tax revenue, whilst exchange rate, inflation and urbanization were found to exert a negative impact.

Ayenew (2016) examined the main factors influencing tax revenue using Johannsen cointegration analysis during the period 1975 to 2013. The findings posited that GDP per capita, industrial sector, foreign aid, had positive impact, whilst inflation had a negative impact on tax revenue. Karagoz (2013) pursued a study to investigate the main drivers of tax revenue in Turkey from 1970 to 2013. Using an OLS technique, the study showed that tax revenue is positively influenced by industrial sector, external debt, money supply, and urbanization rate, but negatively influenced by the agricultural sector. Muibi and Sinbo (2013) investigated the macroeconomic determinants of tax revenue in Nigeria using annual data from 1970 to 2011. The evidence showed while inflation had a negative impact on tax revenue, both exchange rate and income had positive effect. The empirical literature has shown that, tax revenue is determined by various factors including, structural, economic and institutional factors, with varying outcomes. Furthermore, despite the abundant literature on the determinants of tax revenue, there is no country specific study on Sierra Leone. Thus, this study contributes to the existing literature to identify the main determinants of tax revenue in Sierra Leone, a country epitomized by large budget deficit- on account of huge government expenditure albeit low revenue mobilization, high dependence on external funding, modest growth rate and high inflationary pressure.

\section{Model specification}

The empirical model for this study draws largely from the theoretical literature and empirical findings. The variables included in the model are largely influenced by the structure of the Sierra Leone economy and the availability of data. Thus, the study adopts the ARDL bound testing technique for estimation in order to address the objective of the study. The approach is a dynamic heterogeneous model, which provides the framework for the variables in the model to be lagged and difference. The technique is preferred in situations where the variables are of I(0) and I(1), since it gives realistic and efficient estimates (Nkoro and Uko, 2016). The ARDL Bounds Testing approach is also used to establish the existence of cointegration among variables.

The empirical model for this study is given as follow;

$$
\operatorname{LnTR}_{t}=\gamma_{0}+\gamma_{1} L n Y_{t}+\gamma_{2} \operatorname{LnCPI}_{t}+\gamma_{3} \operatorname{LnOP}_{t}+\gamma_{4} \operatorname{LnODA}_{t}+\gamma_{5} \operatorname{LnER}_{t}+\gamma_{6} \operatorname{LnPop}_{t}+\varepsilon_{t}
$$

Where TR is tax revenue, Y represent real GDP growth, CPI is consumer price index (used to measure inflation), OP represent openness, ODA is Official Development Assistance, ER is exchange rate and Pop is population growth. The subscript $\mathrm{t}$ denotes the time dimension, whereas, $\gamma_{0}, \gamma_{i}$ (where $i=1,2, \ldots, 6$ ) is the intercept, parameters to be estimated and $\varepsilon_{t}$ the random error term, which is assumed to be independently and identically distributed with zero mean and constant variance.

As a pre-condition, the identification of the optimal lag length is critical for adopting the ARDL Bounds test. In that light, the study utilizes the Akaike Information Criterion (AIC), Schwarz Information Criterion (SIC), Hannan-Quinn Information Criterion (HQ) and Final Prediction Error (FPE) to select the optimal lag length.

Equation (1) can be transformed and specified in an ARDL form as;

$$
\begin{array}{r}
\Delta L n T R_{t}=\delta_{0}+\sum_{i=1}^{p} \beta_{1 t i} \Delta L n T R_{t-1}+\sum_{i=0}^{q} \beta_{2 t i} \Delta L n Y_{t-1}+\sum_{i=0}^{q} \beta_{3 t i} \Delta L n C P I_{t-1}+ \\
\sum_{i=0}^{q} \beta_{4 t i} \Delta L n O p_{t-1}+\sum_{i=0}^{q} \beta_{5 t i} \Delta L n O D A_{t-1}+\sum_{i=0}^{q} \beta_{6 t i} \Delta L n E R_{t-1}+\sum_{i=0}^{q} \beta_{7 t i} \Delta L n P o p_{t-1}+\theta L n T R_{t-1}+ \\
\alpha_{1} L n Y_{t-1}+\alpha_{2} L n C P I_{t-1}+\alpha_{3 L n} O p_{t-1}+\alpha_{4} L_{n} O D A_{t-1}+\alpha_{5} L n E R_{t-1}+\alpha_{6} L_{n P o p}^{t-1}+\varepsilon_{t}
\end{array}
$$

Where: $p$ and $q$ denote the maximum lag for the dependent and independent variables respectively; $\Delta$ indicates the difference operator; $\delta_{0}$ represents the drift component. In equation (2), the long-run coefficients in the model are represented by $\alpha_{i}^{\prime} s(i=1,2, \ldots, 6)$ while the dynamic components with the $\beta^{\prime} s$ reflect the short-run. Based on equation (2), the study tests for the existence of cointegration. Within the framework of the Bound tests, the 
study proceeds with the null hypothesis of no cointegration against the alternative hypothesis of cointegration. In that;

$$
\begin{gathered}
H_{O}: \beta_{1}=\beta_{2}=\cdots=\beta_{7}=0(\text { No cointegration) } \\
H_{1}: \beta_{1} \neq \beta_{2} \neq \cdots \neq \beta_{7} \neq 0(\text { cointegration })
\end{gathered}
$$

Through this model, critical values reflecting upper bound and lower bound limits are examined against the $F$ statistic of cointegration. The simple rule is that if the $F$-statistic is larger than the upper bound limits critical value at any given significance level, then the null of no cointegration is rejected and therefore confirms the existence of a long-run relationship; otherwise, no cointegration exists and essentially, no long-run relationship. Suppose the F-statistic is larger than the critical value of the upper bound, then equation (2) is reparametrized to reflect an error correction model. A reparametrized ARDL model is presented as thus;

$$
\begin{array}{r}
\Delta L n T R_{t}=\delta_{0}+\sum_{i=1}^{p} \beta_{1 t i} \Delta L n T R_{t-1}+\sum_{i=0}^{q} \beta_{2 t i} \Delta L n Y_{t-1}+\sum_{i=0}^{q} \beta_{3 t i} \Delta L n C P I_{t-1}+ \\
\sum_{i=0}^{q} \beta_{4 t i} \Delta L n O p_{t-1}+\sum_{i=0}^{q} \beta_{5 t i} \Delta L n O D A_{t-1}+\sum_{i=0}^{q} \beta_{6 t i} \Delta L n E R_{t-1}+\sum_{i=0}^{q} \beta_{7 t i} \Delta L n P o p_{t-1}+\sigma E C T_{t-1}+\varepsilon_{t}
\end{array}
$$

Where equation (3) shows a model in first difference that includes an error correction term (ECT), which reflects the model's speed of adjustment for any short-run disequilibrium to the long-run.

The study utilized secondary quarterly data from 1990Q1 to 2020Q1. In total, 121 observations are used for the study. Data on the variables were sourced from the IMF, UNCTAD Stats and the World Bank Economic Output website.

\section{Discussion of results}

\subsection{Correlation Matrix}

Table 1 presents the correlation results. Intuitively, the results provide an insight on the possible relationship between the dependent and independent variables. The result indicates that, the highest correlation score was observed for TR and Y, showing a positive correlation between the variables. Except for CPI and ER, all the other variables show a positive correlation with TR. From the result, we conclude that CPI and ER negatively affect TR; while Y, Op, ODA and Pop affect TR positively. With a correlation coefficient greater than 0.5 , the findings show a strong positive correlation between tax revenue and its determinants ( $\mathrm{Y}$ and $\mathrm{Op}$ ), but a weak correlation with PoP. Also, the findings postulate a strong negative correlation between tax revenue and inflation, but a weak negative correlation with exchange rate.

Table 1. Correlation Matrix

\begin{tabular}{llllllll}
\hline & TR & Y & CPI & Op & ODA & ER & Pop \\
\hline TR & 1.000 & & & & & & \\
Y & 0.795 & 1.000 & & & & & \\
CPI & -0.608 & -0.500 & 1.000 & & & & \\
Op & 0.570 & 0.566 & 0.035 & 1.000 & & & \\
ODA & -0.023 & -0.402 & -0.233 & -0.368 & 1.000 & & \\
ER & -0.137 & -0.249 & 0.021 & 0.118 & 0.146 & 1.000 & \\
Pop & 0.364 & 0.352 & -0.498 & -0.094 & -0.101 & -0.376 & 1.000 \\
\hline
\end{tabular}

Source: Author's computation using output from Eviews 11

\subsection{Results of Unit Root Test}

The study performs a unit root test to ascertain the level of stationarity of the variables. The study employs the ADF technique to test for time series stationarity while the PP test serves as a robust check. The study validates both tests at the 5\% and $1 \%$ levels of significance. The results show that variables are integrated of mixed order: at level $[\mathrm{I}(0)]$ and after taking the first difference $[\mathrm{I}(1)]$. The ADF result confirms that, TR, CPI, ODA and Pop are stationary in levels, i.e. I(0), whilst Y, ER and Op are stationary in first difference- I(1). However, the PP-test reveals that all the variables are characterized as I(1) series, i.e. stationary after first difference, except CPI which is $\mathrm{I}(0)$ series, i.e. stationary in level. 
Table 2. Stationarity Test

\begin{tabular}{lllllll}
\hline & ADF-Test & & \multicolumn{3}{c}{ PP-Test } \\
\cline { 2 - 7 } Variable & level & $\mathbf{1}^{\text {st }}$ diff. & Order & level & $\mathbf{1}^{\text {st }}$ diff. & Order \\
\hline TR & $-3.042^{* *}$ & & $I(0)$ & -2.570 & $-3.688^{* * *}$ & $I(1)$ \\
Y & -0.976 & $-3.563^{* * *}$ & $I(1)$ & -0.814 & $-3.655^{* * *}$ & $I(1)$ \\
CPI & $-4.818^{* * *}$ & & $I(0)$ & $-4.520^{* * *}$ & & $I(0)$ \\
Op & -2.397 & $-2.953^{* *}$ & $I(1)$ & -1.712 & $-3.705^{* * *}$ & $I(1)$ \\
ODA & $-3.751^{* * *}$ & & $I(0)$ & -2.628 & $-3.384 * *$ & $I(1)$ \\
ER & -2.747 & $-3.106^{* *}$ & $I(1)$ & -1.824 & $-3.677^{* * *}$ & $I(1)$ \\
Pop & $-6.812^{* * *}$ & & $I(0)$ & -1.325 & -2.332 & - \\
\hline
\end{tabular}

$* *$ and $* * *$ reflects significance at the $5 \%$ and $1 \%$ level respectively

Source: Author's computation using Eviews 11 output

\subsection{Optimal Lag Selection}

To avoid erroneous estimation results, the study establishes the optimal lag length. The literature suggests that, inaccurately selecting a lag length (over or under) will likely produce misleading and imprecise estimation results. The study utilizes four lag length selection criteria to validate the preferred lag length for the model. The result as presented in Table 3, indicates an optimal lag of two (2) consistent with the selection criteria. Generally, optimal lag lengths between 1 to 8 is considered appropriate for quarterly data (Adeleye, 2018).

Table 3. Optimal Lag Selection Criteria

\begin{tabular}{lllll}
\hline Lag & FPE & AIC & SC & HQ \\
\hline 0 & 3690.42 & 28.08 & 28.24 & 28.15 \\
1 & $5.12 \mathrm{e}-09$ & 0.77 & 2.10 & 1.31 \\
2 & $1.17 \mathrm{e}-11^{*}$ & $-5.31^{*}$ & $-2.84^{*}$ & $-4.31^{*}$ \\
3 & $2,19 \mathrm{e}-11$ & -4.71 & -1.08 & -3.24 \\
4 & $3.39 \mathrm{e}-11$ & -4.32 & 0.48 & -2.37 \\
\hline
\end{tabular}

*Indicates lag order selected by the criterion

Source: Author's computation

\subsection{Bounds Cointegration Test Results}

The study uses the ARDL bounds test cointegration approach after it was established that the variables are stationary of mixed order, that is, $\mathrm{I}(0)$ and $\mathrm{I}(1)$. The test determines whether a long-run association among the variables exists by testing the null hypothesis of no cointegration against the alternative of cointegration. The null is rejected if the F-statistic exceeds the upper bound (limit) at the 10\% and 5\% significance levels; otherwise, we confirm there is no cointegration. From the result presented in Table 4, the F-statistic (3.39) is found to be greater than the upper bound, I(1), at the 5\% and 10\% levels of significance. Therefore, the study concludes there is cointegration, indicating there is a long-run relationship among the variables.

Table 4. ARDL Bounds Test Result

\begin{tabular}{lllll}
\hline Test Statistic & Value & Level of Significance & I(0) & I(1) \\
\hline F-statistic & 3.390 & $10 \%$ & 1.99 & 2.94 \\
K & 6 & $5 \%$ & 2.27 & 3.28 \\
Asymptotic: $n=1000$ & & & & \\
\hline Sorce
\end{tabular}

Source: Author's computation

\subsection{Long-Run ARDL Estimation Results}

Table 5 present the long-run ARDL estimation results. The findings show that, the most significant determinants of tax revenue in Sierra Leone during the study period are Y, Op and ODA. Intuitively, the result reveals that a one percentage increase in real GDP (Y) will increase tax revenue by 1.7 percent in Sierra Leone. The result suggests that raising the level of economic activities would increase the amount of revenue collected by the 
government. Through increased growth, the level of development and living standards is likely to improve, thus, enhancing domestic tax revenue mobilization efforts. The result is significant at the $1 \%$ significance level, and the finding is consistent with Cung and Son (2020) and Wawire (2017). Furthermore, the Openness to Trade (Op) variable is found to affect tax revenue positively and significant at the 5\% level. Thus, a one percentage increase in trade openness will cause tax revenue in Sierra Leone to increase by 0.04 percent. The result suggests that the more open a country's economy, through increasingly liberalized economic policies, the more likely the flow of trade and subsequently the increase in tax revenue. Similar result was obtained by Gobachew et al. (2018) and Gnangnon and Brun (2019). Similarly, ODA has a positive impact on tax revenue at the $1 \%$ significance level. The result reveals that a one percentage increase in ODA will raise tax revenue by 0.1 percent. The literature suggests that ODA through loans will increase tax revenue efforts which will subsequently increase revenue generating potential in a given country (Terefe and Teera, 2018). However, the finding is in contrast to the empirical work by Bayu (2015) and Jabari (2020) who found the reverse for Ethiopia and Lesotho respectively.

Table 5. Long-Run ARDL Estimation Result

\begin{tabular}{lllll}
\hline Variable & Coefficient & Standard Error & $\boldsymbol{t}$-Statistic & $\boldsymbol{p}$-value \\
\hline LnGDP & 1.714 & 0.506 & 3.391 & 0.001 \\
LnCPI & -0.018 & 0.012 & -1.443 & 0.152 \\
LnOp & 0.037 & 0.016 & 2.315 & 0.023 \\
LnODA & 0.095 & 0.035 & 2.722 & 0.008 \\
LnER & 0.499 & 1.601 & 0.312 & 0.756 \\
LnPop & 0.122 & 0.171 & 0.715 & 0.476 \\
-Cons & -34.713 & 15.659 & -2.217 & 0.029 \\
\hline
\end{tabular}

Source: Author's computation using output from Eviews 11

\subsection{Short-Run ARDL Estimation Results}

The short-run ARDL estimation result is presented in Table 6. The model was estimated using an ARDL lag structure of $(2,2,2,0,2,0,0)$ based on the AIC. Critical review of the result shows that, the speed of adjustment term, ECT, is statistically significant at the $1 \%$ level of significance. The findings indicate that any short-run disequilibrium to the long-run can be corrected at the 11 percent speed of adjustment quarterly. While the result reaffirms there is a long-run relationship, its adjustment speed is low. Furthermore, results of the short run are consistent with the long run findings. The results as shown in Table 6, reveals that lagged tax revenue, real GDP, inflation and official development assistance are the key determinants of tax revenue in the short run. The result confirms that the first lag of the dependent variable (TR) affects tax revenue positively. Thus, a percentage increase in the lagged value of tax revenue leads to an increase in tax revenue by $0.8 \%$ in the short-run. The result implies that the current tax revenue is positively impacted by the previous quarterly period's tax revenue. In tandem with the long run, the short run findings show that a one percentage increase in Y will lead to an increase in TR by 2.3 percent. Furthermore, the result indicates that a one percentage increase in ODA will increase TR by 0.04 percent. Also, a one percentage increase in the level of inflation (CPI) will reduce TR by 0.04 percent in the short run. In addition, it was established that over 75 percent of the variation in the dependent variable is explained by the regressors as indicated by R-squared.

Table 6. Short-Run ARDL Estimation Result (2, 2, 2, 0, 2, 0, 0)

\begin{tabular}{lllll}
\hline Variable & Coefficient & Standard Error & $\boldsymbol{t}$-Statistic & $\boldsymbol{p}$-value \\
\hline DLn(TR(-1)) & 0.791 & 0.055 & 14.328 & 0.000 \\
DLn(GDP) & 2.312 & 0.781 & 2.958 & 0.004 \\
DLn(GDP(-1)) & -2.013 & 0.762 & -2.641 & 0.010 \\
DLn(CPI) & -0.046 & 0.009 & -5.393 & 0.000 \\
DLn(CPI(-1)) & 0.033 & 0.009 & 3.552 & 0.001 \\
DLn(ODA) & 0.043 & 0.018 & 2.388 & 0.019 \\
DLn(ODA(-1)) & -0.043 & 0.018 & -2.344 & 0.021 \\
ECT(-1) & -0.107 & 0.020 & -5.380 & 0.000 \\
\hline R-Squared & & 0.761 & & \\
Adjusted R-squared & & 0.745 & & \\
Durbin-Watson Stats & & 2.13 & & \\
\hline
\end{tabular}

Source: Author's computation using output from Eviews 11 


\subsection{Diagnostic Tests}

The model was diagnosed for serial correlation, heteroscedasticity and stability through a series of diagnostic tests. The results are presented in Table 7 (serial correlation and heteroscedasticity) and Figure 3 (stability). The results as shown in Table 7, indicates that the model is free from serial correlation as the study fails to reject the null of no serial correlation under the Breusch-Godfrey Serial Correlation LM Test. Furthermore, based on the BreuschPagan-Godfrey Heteroscedasticity Test result, the study cannot reject the null of homoscedasticity, thus, concluding that the variance of the residuals is constant.

Table 7. Serial Correlation and Heteroscedasticity Tests

\begin{tabular}{lll}
\hline Statistic & F-statistic & Pvalue \\
\hline Breusch-Godfrey Serial Correlation LM Test & 0.478 & 0.621 \\
Breusch-Pagan-Godfrey Heteroscedasticity Test & 1.325 & 0.205 \\
\hline
\end{tabular}

Source: Author's computation using output from Eviews 11

Finally, the study tests for model stability using the Cumulative sum (CUSUM) test. Using time series data, it is assumed that the model coefficients are stable over time, hence, the relevance of this test. As shown in Figure 2, the result suggests that the model coefficients are stable given that the CUSUM is found within the critical band of 5 percent level of significance.

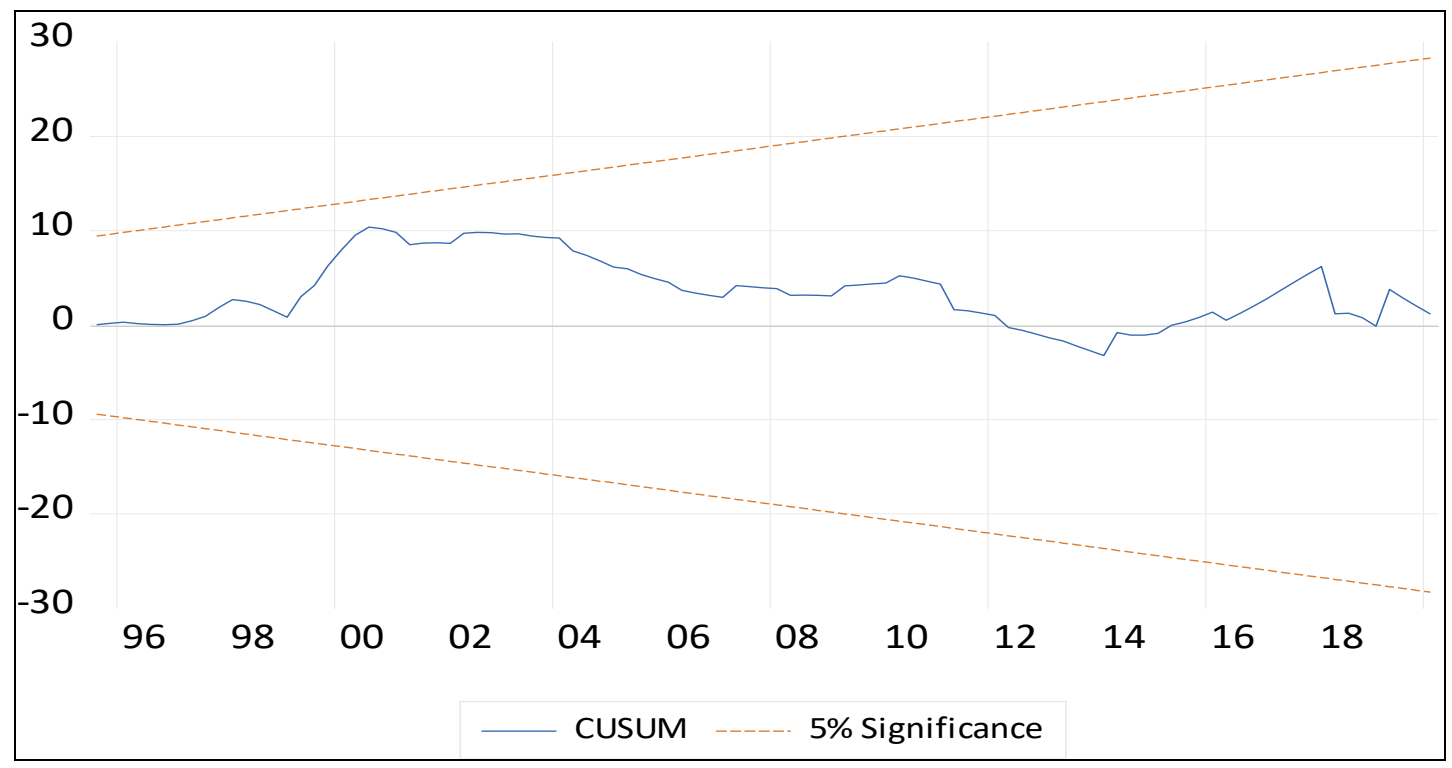

Figure 2. Model Stability Test

Source: output from Eviews 11

\section{Conclusion}

The aim of the study was to empirically identify the determinants of tax revenue in Sierra Leone, given that the country remains highly aid-dependent while domestic revenue mobilization remains relatively low. The study utilized the ARDL estimation procedure for analysis, with quarterly data for the period 1990Q1 to 2020Q1. The result from the ARDL Bound test for cointegration revealed that a long-run relationship exists among the variables under study. The findings confirmed that real GDP (Y), openness (Op) and official development assistance (ODA) were the main long run determinants of tax revenue (TR) in Sierra Leone. All these variables had positive impact on tax revenue. In tandem with the long run, the short run findings also indicated that real GDP (Y), Inflation (CPI) and official development assistance (ODA) were the main determinants of tax revenue in Sierra Leone. Whilst Y and ODA had positive impact on TR, inflation had a negative impact in the short run. Furthermore, it was confirmed that any short-run disequilibrium to the long-run can be corrected at the 11 percent speed of adjustment quarterly, albeit at a low speed of adjustment. The diagnostic result showed that approximately 75 percent of the variation in the regressand is explained by the regressors as indicated by R-squared. Finally, the tests further 
confirmed that the model is free of serial correlation and heteroscedasticity, while the CUSUM test indicate stability of the model coefficients.

One key policy implication is for government to pursue policies that will enhance economic growth. That is, government should investment in growth enhancing sectors including agriculture, health, education, energy and telecommunication; and ensure a politically stable environment for private sector investment. Furthermore, government should implement policies that seeks to encourage further liberalization of the economy, by signing up to national, regional and international trade agreements, as well as designing favourable domestic trade policies.

\section{References}

Abdixhiku, L., Krasniqi, B., Pugh, G., \& Hashi, I. (2017). Firm-level Determinants of Tax Evasion in Transition Economies. Economic Systems, 41(3), 354-366. https://doi.org/10.1016/j.ecosys.2016.12.004

Addison, T., \& Levin, J. (2012). The determinants of tax revenue in sub-Saharan Africa. Retrieved $21^{\text {st }}$ August 2021 from http://www.diva-portal.org/smash/get/diva2:570456/FULLTEXT01.pdf

Adeleye, N. B. (2018). Time series analysis: Choosing optimal lags in Eviews. Retrieved September $8^{\text {th }}$, 2021, from http://cruncheconometrix.blogspot.com/2018/02/time-series-analysis-lecture-2-choosing.html

Aggrey, J. (2013). Determinants of tax revenue: Evidence from Ghana. Master's Thesis, University of Cape Coast.

Agbeyegbe, T. D., Stotsky, J., \& WoldeMariam, A. (2006). Trade liberalization, exchange rate changes, and tax revenue in Sub-Saharan Africa. Journal of Asian Economics, 17(2), 261-284. https://doi.org/10.1016/j.asieco.2005.09.003

AL-Qudah, A. M. (2021). The Determinants of Tax Revenues: Empirical Evidence From Jordan. International Journal of Financial Research, 12(3), Special Issue, 2021. https://doi.org/10.5430/ijfr.v12n3p43

Amoh, J. K., \& Adom, P. K. (2017). The Determinants of Tax Revenue Growth of an Emerging Economy - the Case of Ghana. Int. J. Economics and Accounting, X(Y), 1-17. https://doi.org/10.1504/IJEA.2017.092280

Ansari, M. M. (1982). Determinants of tax ratio: A cross-country analysis. Economic and Political Weekly, 17(25), $1035-1042$.

Ayenew, W. (2016). Determinants of tax revenue in Ethiopia (Johansen co-integration approach). International Journal of Business, Economics and Management, 3(6), 69-84. https://doi.org/10.18488/journal.62/2016.3.6/62.6.69.84

Bayu, T. (2015). Analysis of tax buoyancy and its determinants in Ethiopia (cointegration approach). Journal of Economics and Sustainable Development, 6(3).

Boukbech, R., Bousselhami, A., \& Ezzahid, E. (2018). Determinants of tax revenues: Evidence from a sample of Lower Middle-Income countries. Applied Economics and Finance, 6(1), 11-20. https://doi.org/10.11114/aef.v6i1.3280

Castro, G. Á., \& Camarillo, D. B. R. (2014). Determinants of tax revenue in OECD countries over the period 20012011. Contaduría y administración, 59(3), 35-59. https://doi.org/10.1016/S0186-1042(14)71265-3

Cung, N. H., \& Son, T. T. (2020). Determinants of Corporate Income Tax Revenue in Vietnam. Advances in Management and Applied Economics, 10(1), 89-103.

Garg, S., Goyal, A., \& Pal, R. (2014). Why Tax Effort Falls Short of Capacity in Indian States: A Stochastic Frontier Approach. Indira Gandhi Institute of Development Research (IGIDR), WP-2014-032.

Gupta, A. S. (2007). Determinants of tax revenue efforts in developing countries. IMF Working Papers, 2007(184). https://doi.org/10.5089/9781451867480.001

Gnangnon, S. K., \& Brun, J. F. (2019). Trade openness, tax reform and tax revenue in developing countries. The World Economy, 42(12), 3515-3536. https://doi.org/10.1111/twec.12858

Gobachew, N., Debela, K. L., \& Shibiru, W. (2018). Determinants of Tax Revenue in Ethiopia. Economics, 6(6), 58. https://doi.org/10.11648/j.eco.20170606.11

Gurdal, T., Aydin, M., \& Inal, V. (2020). The Relationship between Tax Revenue, Government Expenditure, and Economic Growth in G7 Countries: New Evidence from time and Frequency Domain Approaches. Econ Change Restruct. https://doi.org/10.1007/s10644-020-09280-x

Jabari, R. (2020). Determinants of tax revenue mobilisation in Lesotho. (Thesis, University of Botswana).

Jafferi, A. A., Tabassum, F., \& Asjed, R. (2015). An Empirical Investigation of the Relationship between Trade 
Liberalization and Tax Revenue in Pakistan. Pakistan Economic and Social Review, 53(2), 317-330.

Karagoz, K. (2013). Determinants of Tax Revenue: Does Sectorial Composition Matter. Journal of Finance, Accounting and Management, 4(2), 50-63.

Muibi, S. O., \& Sinbo. O. O. (2013). Macroeconomic Determinants of Tax Revenue in Nigeria (1970-2011). World Applied Sciences Journal, 28(1), 27-35.

Neog, Y., \& Gaur, A. K. (2020). Macro-economic determinants of tax revenue in India: an application of dynamic simultaneous equation model. International Journal of Economic Policy in Emerging Economies, 13(1), 1335. https://doi.org/10.1504/IJEPEE.2020.106679

Nkoro, E., \& Uko, A. K. (2016). Autoregressive Distributed Lag (ARDL) cointegration technique: application and interpretation. Journal of Statistical and Econometric methods, 5(4), 63-91.

OECD/ATAF/AU. (2020). Revenue Statistics in Africa 2020. Retrieved October 29 2021 from https://www.oecd.org/ctp/revenue-statistics-in-africa-2617653x.htm

Ojong, C. M., Anthony, O., \& Arikpo, O. F. (2016). The impact of tax revenue on economic growth: Evidence from Nigeria. IOSR Journal of economics and finance, 7(1), 32-38.

Takumah, W., \& Iyke, B. N. (2017). The links between economic growth and tax revenue in Ghana: an empirical investigation. International Journal of Sustainable Economy, 9(1), 34-55. https://doi.org/10.1504/IJSE.2017.080856

Terefe, K. D., \& Teera, J. (2018). Determinants of tax revenue in East African countries: An application of multivariate panel data cointegration analysis. Journal of Economics and International Finance, 10(11), 134155. https://doi.org/10.5897/JEIF2018.0924

UNCTAD. (2010). Investment Policy Review of Sierra Leone. United Nations Conference on Trade and Development New York and Geneva: United Nations.

Wawire, N. (2017). Determinants of value added tax revenue in Kenya. Journal of Economics Library, 4(3), 322344.

Wujung, V. A., \& Aziseh, F. I. (2016). Assessing the effect of domestic resource mobilization on the economic growth of Cameroon. Aestimatio: The IEB International Journal of Finance, (12), 66-89. https://doi.org/10.5605/IEB.12.4

\section{Copyrights}

Copyright for this article is retained by the author(s), with first publication rights granted to the journal.

This is an open-access article distributed under the terms and conditions of the Creative Commons Attribution license (http://creativecommons.org/licenses/by/4.0/). 